\title{
Why should the gravity model be taught in business education?
}

\author{
Anca TAMAȘ \\ Bucharest University of Economics Studies, Bucharest, Romania \\ anca.tamas@rei.ase.ro
}

\begin{abstract}
The aim of this paper is to critically analyze the papers from the literature mainstream regarding the gravity model and to identify the main findings. The paper highlights the importance of studying the gravity model in the tertiary business education. Introduced by Tinbergen (1962), the gravity model was widely used to analyze the international trade flows in theoretical, as well as empirical studies. Alongside the classical determinants, economy size, market size and geographical distance, other variables which influence the trade flows were found: trade agreements, foreign direct investments, exchange rate, trade taxes, cultural distance, migration, remoteness, knowledge capital, technological development. There are many controversies regarding the zeroes problem within the model, as well as many controversies on the solutions of the zeroes problem. A meta-analysis and systematic review of the relevant literature in the last 56 years was conducted. From author's knowledge, this study is the most extended literature review on the gravity model, covering more than 50 years of research. Despite all the theoretical controversies, the gravity model proved to be a robust one, with a great power of explanation in more than $80 \%$ of the dynamics and structure of the trade flows. Therefore, the gravity model should be considered a valuable analysis tool in teaching and studying in tertiary business education: international trade, econometrics, statistics, trade policy and so on.
\end{abstract}

Keywords: gravity model, literature review, international trade, trade determinants, tertiary education.

\section{Introduction}

The aim of this paper is to realize a critical review of the papers from the international literature regarding the gravity model and to identify the main research directions. The paper reveals the importance of studying the gravity model at the university level.

The paper is a meta-analysis of the relevant literature regarding the gravity model. First, it presents the main determinants of the trade flows, the classic determinants, like the economy size or the geographical distance, but also other determinants, like the trade agreements, the exchange rate, the trade costs and also some dummy variables (common border, common language and colonial links). The study brings empirical evidence to the Linder's hypothesis (if two countries have the same demand characteristics, they tend to develop more bilateral trade). The paper presents the theoretical background, the methodology and some practical cases of applying the gravity model on developed countries and also on developing ones. In the final part, the study includes some recommendations of applying the gravity model on different types of services and also of introducing it in the university curricula, to have real and practical case studies, not just theoretical and arbitrary ones.

57 years after Tinbergen's paper on the gravity model, researchers are far from getting to a consensus and the original questions are still waiting for the proper and comprehensive answers. Which are the determinants of the international trade flows? Which economic model(s) are generating the gravity equations? How to cope with the heteroscedasticity, which seems to be a common feature of the real data? Which is the best way to address the problem of the zero flows? In order to estimate the gravity equation, is it better to take the log-linear approach or the nonlinear one? Does the gravity model work for tangible goods only or it can be extended to non- 
tangible goods or to services? Should the gravity model be studied in economic universities? The paper tries to find answers to these questions.

\section{Literature review: Meta analyses of the relevant literature and recommendations for future studies Determinants of the trade flows}

\section{Economy size}

„The economic size of the trading countries would have a positive impact on the trade flows", stated Tinbergen in 1962 and each and every researcher confirmed that ever since. But what should be the proper measure for the economic size? GNP (now known as GNI) as in the original paper of Tinberger, the incomes of the trading countries (Abrams, 1980), the real GDP growth, which explains more than $67 \%$ of the trade growth (Baier \& Bergstrand, 2001), the GDP similarities (Linder, 1961) ${ }^{1}$, inequalities between GDP or GDP per capita (Bergstrand, 1990)? Most studies consider either GDP or GDP per capita and the estimated coefficients are usually between 0.2 and 1 (Head, 2003).

\section{The distance}

The distance between two countries has a negative impact on their bilateral trade flows (Abrams, 1980 ) and the role of the distance between the trading countries is persistant in all gravity models (Egger, 2008). The distance seems to be a time invariant, yet Brun et al. (2005), studying the bilateral trade between 130 countries in the period 1962-1996, found that the coefficient for distance decreased with 11\%, while Disdier \& Head (2008), analyzing 1500 distances in 100 studies, found that the the negative coefficients of the distance reached their highest value arround the middle of the century and remained so. The distance coefficients are larger at extensive margin of the export compared to the intensive one (Lawless, 2010). According to Khan (2011), the coefficients for distance should be between -0.6 to -1.6 when reffering to tangible goods. The distance between two countries matters for taste dependent digitaly products, like music or games, a $1 \%$ increase in physical distance will lead to a $3,25 \%$ decrease on the websites' visits (Blum \& Goldfarb, 2006). There are flows where the distance does not matter at all: for non-taste dependent products like software (Blum \& Goldfarb, 2006) or Erasmus students' flows (Tamaş, 2017).

Most studies are taking into account the distance between capital cities of the two trading countries, but some of them are referring to internal distance as computed in geo_cepii, based on the land area, remoteness of a country, landlocked countries. In this respect, internal distance has a 10 times larger negative impact on the trade flows compared to the remoteness of the country (Melitz, 2007) and the coefficients for landlocked should range in -0.3 to -1 (Khan, 2011).

\section{The trade agreements}

The membership in the same trade organization has a power explanatory influence on the trade flows (Abrams, 1980) and an average between 23 to 26 percents of the trade growth among the OECD countries could be explained by the trade taxes cuts and by the trade agreements (Baier \& Bergstrand, 2001). Positive effects of the trade agreements were found: The Economic European

\footnotetext{
${ }^{1}$ Hallak,JC 2010. "A Product-Quality View of the Linder Hypothesis," The Review of Economics and Statistics, MIT Press, vol. 92(3), pages 453-466, August.
} 
Community (EEC) determined a greater gross trade creation (GTC) on the members trade compared to the European Free Trade Association (EFTA) (Aitken, 1973). Long run effects between 1960 and 2000 of the membership in the EEC or in the Central American Common Market (CACM) on the trade were found (Baier \& Bergstrand, 2009). ACFTA, the free trade agreement between China and the countries in ASEAN, would have a larger impact than the conventional gravity model predicts (Roberts, 2004). But there are some doubts too: the gravity model tends to overestimate the effects of integration in a trade organization, mainly if heterogeneity is underestimated (Cheng \& Wall, 1999). Antonucci \& Manzocchi (2006) found that there was no evidence of additional trade between EU and Turkey as a result of the association agreement (1963) and of the customs union (1996).

A Free Trade Agreement (FTA) could double the bilateral trade in 10 years (Baier \& Bergsrtand, 2007). If a pair of countries already having a free trade agreement (FTA) will have one more FTA with a third country, the impact on the trade flows among the three countries will be fifty times larger compared to the impact of an additional FTA of any of the two countries with a third country (Baier \& Bergstrand, 2004).

Although the preferential trade agreements (PTA) increase the bilateral trade, the dummies used for PTA in gravity equation do not capture the whole PTA effect on the bilateral trade (Cardamone, 2007).

Regional trade agreements (RTA) lead to an increase of the trade among RTA members, mostly on the expense of the others (Carerre, 2006). RTA have a significant impact on trade flows, irrespectively of the differences in considered datasets, sample sizes or independent variables (Cipollina \& Salvatici, 2010). Using a dynamic version of the gravity model, MartínezZarzoso et al. (2009) found out that RTA have larger effects for developed countries comparing to developing countries.

\section{The exchange rate}

The first study that emphasizes the negative impact of the uncertainy of the exchange rate and not of the exchange rate itself on the trade flows was the one of Abrams (1980). Exchage rate has a significant impact on the bilateral trade, in both versions: real exchange rate or nominal exchange rate (Thursby \& Thursby, 1987).

\section{The trade costs}

Bilateral trade costs changes determine small effects, although multilateral fail of the trade costs will determine the reduction of the bilateral trade (Behar \& Nelson, 2014). On average, 8 to $9 \%$ of the trade growth among the OECD countries could be explained by the decrease of the transport costs (Baier \& Bergstrand, 2001).

The trade costs might vary across product lines with a factor of at least 10 (Anderson \& van Wincoop, 2004). The elasticity of the products' substitution decreases the impact of the trade barriers on the trade flows (Chaney, 2008).

The gravity model is a valuable tool in computing the counterfactuals, like the impact of reducing the trade costs on the trade flows (Egger, 2002). The coefficients of the import tariff should be between - 0.1 to - 0.5 (Khan, 2011).

The bilateral trade costs is the main exploratory variable in the gravity equations for the aproximation errors (Baier \& Bergstrand, 2009). 
Developing countries experience trade costs seven times larger than the developed countries (Anderson \& van Wincoop, 2004).

\section{Linder's hypothesis}

If two countries have the same demand characteristics, they tend to develop more bilateral trade (Abrams, 1980). The gravity equation will better fit for countries with the same preferences on the traded goods, with similar transport structures and similar trade taxes (Anderson, 1979).

Empirical evidence of Linder's hypothesis was found for EU 15, USA, Japan and 57 of their trade partners between 1986 and 1997 (Baltagi et al., 2003). An overwhelming support for the Linder's hypothesis was found by Thursby \& Thursby (1987), that being in contradiction with the previous studies, which showed that the gravity model tends to reject Linder's hypothesis.

\section{Common border, common language and colonial links}

The estimated coefficients for a common border should be around 0,5 , meaning that sharing a border would increase the trade flows with about $65 \%$ and this value stands even though there is also a distance variable (Head, 2003). Keith \& Mayer (2002) found that the common border effect is overestimated by six times using the traditional gravity model.

If two countries share a common language, the trade will be two to three times greater compared to countries which do not share a common language. If a variable for colonial links is introduced, the effect of the common language will decrease, but both of them will remain positive (Head, 2003).

OLS estimation exaggerates the role of colonial ties, as well as the role of geographical proximity (Santos Silva \& Tenreyro, 2006).

\section{Theoretical approach}

Theoretical ground

Gravity model first appeared in text books in 2004, introduced by Feenstra. Gravity model seems to be the most useful empirical model which explains the distribution of goods and works on any scale (Anderson, 2011). Although the gravity model is a good fit under different circumstances, it has its limitations because of its unidentified properties (Anderson, 1979).

One of the limitations of the theory the gravity model is based on is that all countries import one good from all countries, while in practice the imports are from a restrictive number of producers (Anderson \& van Wincoop, 2003).

The gravity model derives from other models, such as the monopolistic competition model for differentiated goods or the Armington's product differentiation for homogeneous goods (Feenstra et al., 2001). The gravity equation could be generated by a model with incomplete specialization, taking into account the trade costs (Haveman \& Hummels, 2004). The monopolistic competition theory, the general equilibrium theory, the partial equilibrium theory and the main firm orientated theories are presented and compared in Koutsoyannis (1997).

Arkolakis et al. (2012) compared the Ricardian model and the Melitz model in an attempt to find the theoretical ground of the gravity model. Bergstrand (1985) found empiric proves that the gravity equation is a reduced form of a partial equilibrium system (Bergstrand, 1989). The gravity model fits in with the Heckscher-Ohlin model of inter-industry trade, as well as with the Helpman-Krugman-Markusen models of intra-industry trade (Bergstrand, 1989). The 
monopolistic competition theory explains better the gravity equation compared to HO model for the trade among industrial countries (Evenett \& Keller, 2002).

Deardoff (1998) examined the deeper relationship between the Heckscher-Ohlin model of international trade (HO) and the classical gravity equation with or without trade frictions (which is with or without trade barriers of any kind).

The structure of the International Trade Network (ITN) could be better explained

PICBE | 426 combining the gravity model with the topological properties of the ITN (Fagiolo, 2010). The gravity model is able to predict a network with homogeneous topology, while ITN is a network with highly heterogeneous structure (Almog et al., 2019).

A stochastic varying coefficient gravity model was introduced by Tzouvelekas (2007) in order to include the country pair heterogeneity.

\section{Methodology}

After 50 years of studying the gravity model, the researchers agreed on some issues: panel estimations should be used instead of cross section estimations, in most cases fixed effects should be chosen, the zero values include information which cannot be ignored (De Benedictis \& Salvatici, 2011).

The linear aproximation method used in the gravity model have lower static errors (Baier \& Bergstrand, 2009).

The nonparametric cross-section estimates are better than the OLS cross section estimates on the usually gravity equations (Baier \& Bergstrand, 2009).

The multilateral trade resistance factors problem, specific to cross section panel data, can be addressed using the time varying country dummies instead of time invariant pair dummies (Baldwin \& Taglioni, 2006).

The OLS dummy estimator outperformed the generalized methods of movements for a dynamic panel gravity model of 221 bilateral trades of OECD countries over 48 years, as well as the dynamic model outperformed the static one (Bun \& Klaassen, 2002).

Using the logarithm in the gravity equation will lead to the problem of treating the zeroes. The Poisson specification of the gravity model addressed the zeroes problem, but it leads to over dispersions of the zeroes' flows (Burger et al., 2009).

The same gravity equation may lead to different results if a dynamic estimator is used instead of a static one, usually a dynamic estimator would give better results in terms of standard errors of regression (De Benedictis \& Vicarelli, 2005).

Over the time, trading block dummies show small variations and these variations enable to get effects of the trading blocks on the trade volumes on short time or on long time (Egger, 2004).

The way the gravity model could explain the International Trade Network (ITN) structure depends on the degree the binary structure replicates the observed structure. The better the binary structure replicates the existed one, the worse the gravity model is able to explain ITN (Duenas \& Fagiolo, 2013).

A panel gravity model including exporters, importers, time and time invariant bilateral effects should properly explain a large variation of the trade flows (Egger \& Pfaffermayr, 2003).

The estimator regarding the fixed effects is similar with the dynamic OLS, considering the non-stationarity of the independent variables (Firdmuc, 2009). 
The Poisson regression outperforms the OLS one in estimating the coefficients in the gravity model of trade flows (Siliverstovs \& Schumacher, 2008).

A modified gravity model was used for studying the meat trade, the coefficients were estimated using time series and cross-section data (Koo et al., 1994).

Over the time, various approaches dealing with zero flows were considered: Tobit estimation, truncated regression, substitutions for zero flows, yet the simplest approach to omit the zero flows from the sample often leads to the most acceptable results (Linders \& de Groot, 2006).

One of the toughest problems of the gravity model is the presence of both heteroscedasticity and frequent zero flows. The Poisson Pseudo-Maximum Likelihood estimator solves the heteroscedasticity bias problem if the zero flows are not frequent and the Tobit estimator solves the frequent zero flows problem if the heteroscedasticity bias problem is satisfactory dealt with (Martin \& Pham, 2008).

A proper gravity model should include fixed country effects and fixed time effects and a panel approach instead of cross section data (Breuss \& Egger, 1999).

Sanso et al. (1993) questioned the log linearity of the gravity equation and proposed instead a general functional form using the Box-Cox transformations.

If there is evidence of heteroscedasticity, the Poisson Pseudo-Maximum Likelihood estimator should be used instead of log linear model (Santos Silva \& Tenreyro, 2006).

Westerlund \& Wilhelmsson (2009) proposed to use gravity model directly from its nonlinear form using fixed effects Poisson ML estimator.

Poisson Quasi-Maximum Likelihood (QML) is the only QML estimator which preserves total trade flows (Arvis \& Shepherd, 2013). The gravity equation using fixes effects could not be used as a base for a trade policy (De Benedictis \& Vicarelli, 2009).

\section{Applying the gravity model}

On other types of flows than trade flows

An extension of the gravity model for bilateral foreign direct investments (FDI) was introduced by Bergrstrand \& Egger (2007).

Using gravity equations proved to be useful in studying the globalization as well (Bergrstrand \& Egger, 2009).

The gravity model needs to be reconsidered for the trade with parts and components (Baldwin and Taglioni, 2010).

The gravity model combined with entropy maximization model was also extended to analyze transportation or journeys to work (Erlander \& Stewart, 1990).

The gravity model together with topologic properties and power - law are used to analyze the Seoul subway system (Goh et al., 2012).

The traffic flows of the Korean highway system behave like a gravity model, found out Jung et al. (2008).

For public transport in England and Wales, the gravity model has a better overall performance, while the parameter free radiation model give more competitive results, mainly at large scale (Masucci et al., 2013).

Inter cities communication intensity and communication flows in Belgium are characterized by a gravity model, although this extension should be considered with caution because of the specific nature of data and the specific of the country (Krings et al., 2009). 
The gravity model fits to multinational firms and especially to highly technology industries, as well as to industries focused on research and development (Keller \& Yeaple, 2009).

A gravity equation was generated by two general equilibrium models involving multinational firms: a symmetric firm model and a heterogeneous firm model (Kleinert \& Toubal, 2010).

Park et al. (2018) developed a generalized gravity model to study human migration,

PICBE | 428 especially subpopulations flows in Korea.

Porojan (2001) included space effects into the gravity model to study the changes of the trade flows, taken into account spatial econometrics.

The gravity model works very well when analyzing the bilateral gross cross-border equity flows between 14 countries in the period 1989-1996 (Portes \& Rey, 2005). Using a gravity model, Rose and Spiegel (2004) proved that the bank credit is extended using the lines of the international trade.

\section{On the developing countries}

Regional integration or RTA was not a suficient condition for the increase of the trade flows among the Caribbean countries and trade itself is neither good or bad for a developing country, it only offers an opportunity that one can take advantage on or not (Elliott, 2007).

The countries from East Asia changed their trade patterns, being more orientated to EU countries and USA before 2003 and more to other Asian countries after 2003. The trade flows are influenced mainly by the wealth of their partner countries and to a lesser extent by the distance between the countries (Filippini \& Molini, 2003).

Henderson \& Millimet (2008) studied 132 non-industrial countries in the 1948-1997 period using the gravity model and non parametric methods.

The gravity model was used to estimate the potential trade flows between Australia and its partner countries from the Indian Ocean (Kalirajan, 1999).

The cross-section gravity analysis does not allow an empirical conclusion on reaching the potential level of the actual East-West trade (Breuss \& Egger, 1999).

\section{Results and discussions}

Recommendations for future studies: using the gravity model for different kind of services (education (Keller \& Yeaple, 2009; Tamaş, 2017), finance (Rose \& Spiegel, 2004), tourism (Erlander \& Stewart, 1990), transport (Masucci et al., 2013)) and for non-tangible goods (movies, songs, videos, advertising (Blum \& Goldfarb, 2006)), like the mentioned authors already did and even for special kind of goods (medicine, books, creative arts etc.). For each of the above different determinants, the gravity model should be tried, as well as different methodologies and the necessary comparisons conducted. Another research avenue could be reproducing the famous studies (Tinbergen, Egger, Rose, Linder hypothesis etc.), comparing the original results with the new ones.

For students, real projects like the ones involving the gravity model, an open question per se, are truly meaningful and inspiring. Instead of conducted arbitrary and purely educationally studies and case studies, real case studies using the gravity model could be considered. In the same time, there is a need for a new perspective of business education (Bratianu \& Vatamenescu, 2017; Bratianu et al., 2020). 


\section{Conclusion}

In conclusion, the gravity model should be used at a wide range of university seminars. The most important is the econometry seminar, because students would have the chance to work with real panel data, to investigate how choosing different independent variables would influence the results or to test different methodological approaches. Another university seminars where the gravity model could be succsessfully used are: economy (to deeply analyze and compare the economic models behind the gravity model), commerce (since what influences the international trade flows is still an open question), trade policies (to investigate and to forecast how the new trade agreements influence the trade flows), international trade (to combine the gravity model with the radiation model, with topological properties, with entropy issue) and economic mathematics (to get familiar with both linear and non-linear models). The main limitation of the paper is that it hasn't too many examples on applying the gravity model on the developing countries.

\section{References}

Abrams, R. K. (1980, March). International Trade Flows under Flexible Exchange Rates. Economic Review. Federal Reserve Bank of Kansas City, 3-10.

Aitken, N. D. (1973). The Effect of the EEC and EFTA on European Trade: A Temporal CrossSection Analysis. American Economic Review, 63, 881-892.

Almog, A., Bird, R., \& Garlaschelli, D. (2019). Enhanced Gravity Model of Trade: Reconciling Macroeconomic and Network Models. Frontiers in Physics, 7(55), $1-18$.

Anderson, I.E. (1979). A theoretical foundation of the gravity equation. American Economic Review, 69(1), 106-16.

Anderson, J.E. (2011). The Gravity model. Annual Review of Economics, 3, 133-160.

Anderson, J.E., \& van Wincoop, E. (2004). Trade costs. Journal of Economic Literature, 42(3), 691-751.

Anderson, J.E., \& van Wincoop, E. (2003). Gravity with gravitas: a solution to the border puzzle. American Economic Review, 93(1), 171-92.

Anderson, J.E. (1979, March). A Theoretical Foundation for the Gravity Equation. American Economic Review, 69(1), 106-116.

Antonucci, D., \& Manzocchi, S. (2006). Does Turkey have a special trade relation with the EU? A gravity model approach. Economic Systems, 30(2), 157-69.

Arkolakis, C., Costinot, A., \& Rodriguez-Clare, A. (2012). New Trade Models, Same Old Gains?. American Economic Review, 102(1), 94-130.

Arvis, J.-F., \& Shepherd, B. (2013). The Poisson quasi-maximum likelihood estimator: A solution to the "adding up" problem in gravity models. Applied Economics Letters, 20(6), 515-519.

Baier, S.L., \& Bergstrand, J.H. (2007). Do free trade agreements actually increase members' international trade?. Journal of International Economics, 71(1), 72-95.

Baier, S.L., \& Bergstrand, J.H. (2001). The growth of world trade: tariffs, transport costs and income similarity. Journal of International Economics, 53, 1-27.

Baier, S.L., \& Bergstrand, J.H. (2009). Bonus vetus OLS: a simple method for approximating international trede-cost effects using the gravity equation. Journal of International 
Economics, 77(1), 77-85.

Baier, S.L., \& Bergstrand, J.H. (2004). Economic determinants of free trade agreements. Journal of International Economics, 64(1), 29-63.

Baier, S.L., \& Bergstrand, J.H. (2009, February). Estimating the effects of free trade agreements on international trade flows using matching econometrics. Journal of International Economics, 77(1), 63-76.

Baldwin, R., \& Taglioni, D. (2006). Gravity for dummies and dummies for gravity equations. NBER Working Paper $\mathrm{N}^{\circ} 12516$.

Baltagi, B.H., Egger, P., \& Pfaffermayr, M. (2003). A generalized design for bilateral trade flow models. Economic Letters, 80(3), 391-397.

Behar, A., \& Nelson, B.D. (2014, July). Trade Flows, Multilateral Resistance, and Firm Heterogeneity. The Review of Economics and Statistics, 96(3), 538-549.

Bergrstrand, J.H., \& Egger, P. (2007). A knowledge-and-physical-capital model of international trade flows, foreign direct investment, and multinational enterprises. Journal of International Economics, 73, 278-308.

Bergrstrand, J.H., \& Egger, P. (2009). Gravity Equations and Economic Frictions in the World Economy. In Bernhofen, D., Falvey, R., Greenaway, D., Krieckemeier, U. (Eds). Palgrave Handbook of International Trade (pp. 532-571). PalgraveMacmillan Press.

Bergstrand, J.H. (1990). The Hecksher-Ohlin-Samuelson model, the linder hypothesis, and the determinants of bilateral intra-industry trade. The Economic Journal, 100(4), 1216-1229.

Bergstrand, J.H. (1985). The Gravity Equation in International Trade: Some Microeconomic Foundations and Empirical Evidence. Review of Economic and Statistics, 67, 474481.

Bergstrand, J.H., (1989, February). The Generalized Gravity Equation, Monopolistic Competition, and the Factor-Proportions Theory in International Trade. Review of Economics and Statistics, 71(1), 143-153.

Bratianu, C., \& Vatamanescu, E.M. (2017). Students' perception on developing conceptual generic skills for business: A knowledge-based approach. VINE Journal of Information and Knowledge Management Systems, 47(4), 490-505.

Bratianu, C., Hadad, S., \& Bejinaru, R. (2020). Paradigm shift in business education: A competence-based approach. Sustainability, 12(4), 1348-1365.

Blum, B.S., \& Goldfarb, A. (2006). Does the internet defy the law of gravity?. Journal of International Economics, 70(2), 384-405.

Breuss, F., \& Egger, P. (1999). How reliable are the estimations of east-west trade potentials based on cross-section gravity analyses?. Empirica, 26(2), 81-94.

Brun, J.-F., Carrère, C., Guillaumont, P., \& de Melo, J. (2005). Has distance died? Evidence from a panel gravity model. The World Bank Economic Review, 19, 99-120.

Bun, M., \& Klaassen, F. (2002). The importance of dynamics in panel gravity models of trade. Tinbergen Institute Discussion Paper, No. 02-108/2.

Burger, M.J., van Oort, F.G., \& Linders, G.M. (2009). On the specification of the gravity model of trade: zeros, excess zeros and zero-inflated estimation. Spat. Econ. Anal., 4(2), 167-190.

Cardamone, P. (2007). A survey of the assessments of the effectiveness of Preferential 
Trade Agreements using gravity models. International Economics, 60(4), 421473.

Carrere, C. (2006). Revisiting the effects of regional trade agreements on trade flows with proper specification of the gravity model. European Economic Review, 50(2), 223-247.

Chaney, T. (2008). Distorted gravity: the Intensive and extensive margins of International trade. American Economic Review, 98, 1701-1721.

Cheng, I.-H., \& Wall, H.J. (1999, February). Controlling for Heterogeneity in Gravity Models of Trade. Working Paper, Federal Reserve Bank of St. Louis.

Cipollina, M., \& Salvatici, L. (2010). Reciprocal trade agreements in gravity models: A MetaAnalysis. Review of International Economics, 18, 63-80.

De Benedictis, L., \& Taglioni, D. (2011). The Gravity Model in International Trade. In De Benedictis, L., \& Salvatici, L. (Eds.). The Trade Impact of European Union Preferential Policies: An analysis through gravity models (pp. 55-89). Springer. Disdier AC.

De Benedictis, L., \& Vicarelli, C. (2005). Trade potentials in gravity panel data models. Topics in Economic Analysis \& Policy, 5(1), 1-31.

De Benedictis, L., \& Vicarelli, C. (2009). Dummies for gravity and gravity for policies: mission impossible?. Mimeo.

Deardoff, A. (1998). Determinants of bilateral trade: Does gravity work in a neoclassical world?. In Frankel, J.A. (Ed.). The regionalization of the world economy (pp. 731). Chicago, IL: University of Chicago Press.

Duenas, M., \& Fagiolo, G. (2013). Modeling the international-trade network: a gravity approach. Journal of Economic Interaction and Coordination, 8, 155-178.

Egger, P., \& Pfaffermayr, M. (2003). The proper panel econometrics specification of the gravity equation: a three-way model with bilateral interaction effects. Empirical Economics, 28(3), 571-580.

Egger, P. (2004). Estimating regional trading bloc effects with panel data. Review of World Economics, 140(1), 151-66.

Egger, P. (2008). On the role of distance for bilateral trade. World Economics Journal, 31(5), 653-662.

Egger, P. (2002). An econometric view on the estimation of gravity models and the calculation of trade potentials. World Economics Journal, 25(2), 297-312.

Elliott, D.R. (2007). Caribbean regionalism and the expectation of increased trade: insights from a time-series gravity model. The Journal of International Trade \& Economic Development, 16(1), 117-136.

Erlander, S., \& Stewart, N.F. (1990). The gravity model in transportation analysis: theory and extensions. World Cat. Retrieved from: http://www.worldcat.org/isbn/9789067640893.

Evenett, S.J., \& Keller, W. (2002). On theories explaining the success of the gravity equation. Journal of Political Economy, 110(2), 281-316.

Feenstra, R.C., Markusen, J.R., \& Rose, A.K. (2001). Using the gravity equation to differentiate among alternative theories of trade. Canadian Journal of Economics, 34(2), 430-447.

Fidrmuc, J. (2009). Gravity models in integrated panels. Empirical Economics, 37, 435-446. 
Filippini, C., \& Molini, V. (2003). The determinants of East Asian trade flows: a gravity equation approach. Journal of Asian Economics, 14(5), 695-711.

Goh, S., Lee, K., Park, J.S., \& Choi, M.Y. (2012). Modification of the gravity model and application to the metropolitan Seoul subway system. Physical Review E, 86(2), DOI: https://doi.org/10.1103/PhysRevE.86.026102.

Hallak, J.C. (2010, August). A Product-Quality View of the Linder Hypothesis. The Review of Economics and Statistics, 92(3), 453-466.

Hatzigeorgiou, A., \& Lodefalk, M. (2015, December). Trade, Migration and Integration Evidence and Policy Implications. The World Economy. Wiley Blackwell, 38(12), 2013-2048.

Haveman, J., \& Hummels, D. (2004). Alternate Hypotheses and the Volume of Trade: The Gravity Equation and the Extent of Specialization. Canadian Journal of Economics, 37, 199-218.

Head, K. (2008). The puzzling persistence of the distance effect on bilateral trade. Review of Economics and Statistics, 90(1), 37-48.

Head, K. (2003). Gravity for beginners. Canada: University of British Columbia.

Henderson, D.J., \& Millimet, D.L. (2008). Is gravity linear?. Journal of Applied Economics, 23(2), 137-72.

Jung, W.-S., Wang, F., \& Stanley, H.E. (2008). Gravity model in the Korean highway. Retrieved from https://iopscience.iop.org/article/10.1209/0295-5075/81/48005/pdf.

Keith, H., \& Mayer, T. (2002). Illusory Border Effects: Distance Mismeasurements Inflates Estimates of Home Bias in Trade. Working Papers 2002-01. CEPII Research Centre, Paris.

Keller, W., \& Yeaple, S.R. (2009). Gravity in the Weightless Economy. NBER Working Paper No. 15509.

Khan, A. (2011). Empirical Investigation of International Trade Using Gravity Models with Gravitas. University of Wollongong Thesis Collection 1954-2016.

Kleinert, J., \& Toubal, F. (2010). Gravity for FDI. Review of International Economics, 18(1), 113.

Koo, W.W., Karemera, D., \& Taylor, R. (1994). A Gravity Model Analysis of Meat Trade Policies. Agricultural Economics, 10, 81-88.

Koutsoyannis, A. (1977). Theory of Econometrics. An Introductory Exposition of Econometric Methods (Second edition). Hampshire: Macmillan Publishers Ltd.

Krings, G., Calabrese, F., Ratti, C., \& Blondel, V.D. (2009). Urban gravity: a model for intercity telecommunication flows. Retrieved from https://iopscience.iop.org/article/10.1088/1742-5468/2009/07/L07003/pdf.

Lawless, M. (2010). Deconstructing gravity: trade costs and extensive and intensive margins. Canadian Journal of Economics, 43(4), 1149-1172.

Linders, G.J., \& de Groot, H.L.F. (2006). Estimation of the Gravity Equation in the Presence of Zero Flows. Tinbergen Institute Discussion Paper No. 06-072/3.

Martin, W., \& Pham, S.C. (2008). Estimating the Gravity Equation when Zero Trade Flows Are Frequent. Retrieved from

https://www.researchgate.net/publication/24116453_Estimating_the_Gravity_Equation_When_Z ero_Trade_Flows_are_Frequent/link/00b7d51e6dcf9077f2000000/download.

Masucci, A.P., Serras, J., Johansson, A., \& Batty, M. (2013). Gravity versus radiation models: 
On the importance of scale and heterogeneity in commuting flows. Retrieved from

https://journals.aps.org/pre/abstract/10.1103/PhysRevE.88.022812.

Melitz, J. (2007). North, South and distance in the gravity model. European Economic Review, 51(4), 971-991.

Papazoglou, C. (2007). Greece's potential trade flows: a gravity model approach. International Advances in Economic Research, 13(4), 403-414.

Park, H.J., Jo, W.S., Lee, S.H., \& Kim, B.J. (2018). Generalized gravity model for human migration. Retrieved from https://iopscience.iop.org/article/10.1088/1367- 2630/aade6b/pdf.

Porojan, A. (2001). Trade flows and spatial effects: the gravity model revisited. Open Economic Review, 12, 265-280.

Portes, R., \& Rey, H. (2005). The determinants of cross-border equity flows. Journal of International Economics, 65(2), 269-296.

Roberts, B.A. (2004). A gravity study of the proposed China-Asean free trade area. The International Trade Journal, 18(4), 335-353.

Rose, A., \& Spiegel, M.A. (2004). Gravity Model of Sovereign Lending: Trade, Default, and Credit. International Monetary Fund Economic Review, 51, 50-63.

Sanso, M., Rogelio, C., \& Sanz, F. (1993). Bilateral Trade Flows, the Gravity Equation, and Functional Form. The Review of Economics and Statistics, 75, 266-275.

Santos Silva, J.M.C., \& Tenreyro, S. (2006). The log of gravity. Review of Economics and Statistics, 88(4), 641-658.

Siliverstovs, B., \& Schumacher, D. (2008). Estimating gravity equations: to $\log$ or not to $\log$ ? Empirical Economics, 36(3), 645-69.

Tamaş, A. (2017). Romanian Erasmus Students' Flows-Gravity Model Approach, Journal of Eastern Europe Research in Business and Economics, 2017(2017), Article ID 253964, DOI: 10.5171/2017.253964.

Thursby, J.G., \& Thursby, M.C. (1987). Bilateral Trade Flows, the Linder Hypothesis, and Exchange Risk. Review of Economics and Statistics, 69(3), 488-495.

Timbergen, J. (1962). Shaping the World Economy: Suggestions for an International Economic Policy. New York: The Twentieth Century Fund.

Tzouvelekas, V. (2007). Accounting for pairwise heterogeneity in bilateral trade flows: a stochastic varying coefficient gravity model. Applied Economics Letters, 14(12), 927-930.

Westerlund, J., \& Wilhelmsson, F. (2009). Estimating the Gravity Model without Gravity using Panel Data. Applied Economics, 41, 1-9. 